\title{
Positive effects of renal denervation on markers of cardiovascular inflammation and left ventricular mass. 24-months follow-up
}

\author{
Sitkova E.S., Mordovin V.F., Pekarskiy S.E., Ripp T.M., Ryabova T.R., Falkovskaya A. Yu., \\ Lichikaki V.A., Zyubanova I. V., Baev A.E., Gusakova A.M. \\ Cardiology Research Institute, Tomsk National Research Medical Center, Russian Academy of Sciences. \\ Tomsk, Russia
}

Aim. To study the long-term effect of renal denervation (RDN) on left ventricular mass (LVM) and inflammatory markers in resistant hypertensive patients.

Material and methods. Forty-one patients with resistant hypertension and 24-h blood pressure (BP) 158,7 $\pm 15,8 / 87,3 \pm 14,6 \mathrm{mmHg}$, aged $56,6 \pm 10,2$ years, were enrolled in the study and undergone RDN. Mean 24-h BP, left ventricular mass (transthoracic echocardiography), high

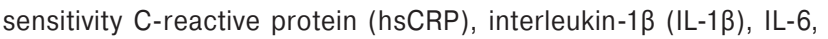
$\mathrm{IL}-10$ ) and tumor necrosis factor alpha (TNF- $\alpha$ ) were assessed at baseline and 2 years after the RDN.

Results. A baseline prevalence of left ventricular hypertrophy (LVH) was 90,2\%. Two years after RDN LVM and interventricular septum (IVS) decreased significantly ( $p<0.05$ for both). Decrease in myocardial mass $(\Delta \mathrm{LVM}>0 \mathrm{~g})$ was documented in 24 patients. The regression of LVM was accompanied by a significant decrease in levels of inflammatory markers - hsCRP by $38,3 \%(p=0,031)$, TNF- $\alpha$ by $60,7 \%(p=0,009), I L-1 \beta-$ by $71,1 \%(p=0,001)$, and IL- 10 by $58,2 \%$ $(p=0,001)$. In patients in the absence of LVM regression only TNF- $\alpha$ decreased significantly $(-68,8 \%, p=0,001)$. There was no correlation between changes of LVM and the inflammatory markers at 24 months after RDN.

Conclusion. The RDN in RH patients may have long-term cardioprotective effect in terms of significant regress of LVH, which may be partly attributed to the regress in systemic or myocardial inflammation.

Keywords: resistant hypertension, cardioprotective efficacy, left ventricular hypertrophy, renal denervation, inflammation.

Relationships and Activities: none.

Trial ID: NCT 02667912.
Sitkova E. S. ${ }^{*}-\mathrm{PhD}$, researcher, department of hypertension, ORCID: 0000-0002-0988-3642, Mordovin V.F. - professor, PhD, the head of department of hypertension, ORCID: 0000-0002-22384573, Pekarskiy S.E. - PhD, Senior research fellow, department of hypertension, ORCID: 0000-0002-4008-4021, Ripp T. M. - PhD, Senior research fellow, department of hypertension, ORCID: 00000001-5898-0361, Ryabova T.R. - PhD, researcher, department ultrasound and functional diagnostic, ORCID: 0000-0001-85735695, Falkovskaya A. Yu. - PhD, Senior research fellow, department of hypertension, ORCID: 0000-0002-5638-3034, Lichikaki V.A. $\mathrm{PhD}$, researcher, department of hypertension, ORCID: 0000-00034066-869X, Zyubanova I.V. - PhD, junior researcher, department of hypertension, ORCID: 0000-0001-6995-9875, Baev A.E. - PhD, head of the Department of Interventional Radiology, ORCID: 00000002-8163-1618, Gusakova A. M. - PhD, researcher, Department of Laboratory and Functional Diagnostics, ORCID: 0000-0002-3147-3025.

*Corresponding author: chekruzhova@mail.ru

ISSN 1728-8800 (Print) ISSN 2619-0125 (Online)

Received: $31 / 08-2020$

Revision Received: 11/12-2020

Accepted: 22/01-2021

\section{(cc) BY 4.0}

For citation: Sitkova E. S., Mordovin V. F., Pekarskiy S. E., Ripp T. M., Ryabova T.R., Falkovskaya A. Yu., Lichikaki V.A., Zyubanova I. V., Baev A.E., Gusakova A. M. Positive effects of renal denervation on markers of cardiovascular inflammation and left ventricular mass. 24-months follow-up. Cardiovascular Therapy and Prevention. 2021;20(2):2678. (In Russ.) doi:10.15829/1728-8800-2021-2678

Положительные эффекты ренальной денервации на маркеры воспаления и массу левого желудочка. Результаты 24-месячного наблюдения

Ситкова Е. С., Мордовин В. Ф., Пекарский С. Е., Рипп Т. М., Рябова Т. Р., Фальковская А. Ю., Личикаки В.А., Зюбанова И. В., Баев А. Е., Гусакова А. М.

Научно-исследовательский институт кардиологии Томского национального исследовательского медицинского центра Российской академии наук. Томск, Россия

*Автор, ответственный за переписку (Corresponding author):

e-mail: chekruzhova@mail.ru

Тел.: 8 (3822) 55-81-22

[Ситкова E. C. ${ }^{*}$ - к.м.н., Н.С. отделения артериальных гипертоний, ORCID: 0000-0002-0988-3642, Мордовин В. Ф. - д.м.н., профессор, руководитель отделения артериальных гипертоний, ОRCID: 0000-0002-2238-4573, Пекарский С. Е. - д.м.н., в.н.с. отделения артериальных гипертоний, ОRCID: 0000-0002-4008-4021, Рипп Т. М. - - М.н., в.н.с. отделения артериальных гипертоний, доцент ФГБОУ ВО СибГМУ Минздрава России, ORCID: 0000-0001-5898-0361, Рябова T.P. - к.M.н., н.С. отделения ультразвуковой и функциональной диагностики, ОRCID: 0000-0001-8573-5695, Фальковская А. Ю. - к.м.н., с.н.с. отделения артериальных гипертоний, ORCID: 0000-0002-5638-3034, Личикаки В.А. - к.м.н., н.с. отделения артериальных гипертоний, ОRCID: 0000-0003-4066869X, Зюбанова И. В. - к.м.н., м.н.с. отделения артериальных гипертоний, ORCID: 0000-0001-6995-9875, Баев А. Е. - к.м.н., зав. отделения рентгенхирургических методов диагностики и лечения, ORCID: 0000-0002-8163-1618, Гусакова A. M. - К.м.н., н.С. отделения функциональной и лабораторной диагностики, ORCID: 0000-0002-3147-3025]. 
Цель. Изучить долгосрочные эффекты ренальной денервации (РД) на массу левого желудочка (МЛЖ) и маркеры воспаления у пациентов с резистентной артериальной гипертензией (АГ).

Материал и методы. В исследование был включен 41 пациент с резистентной АГ (среднесуточное артериальное давление (АД) $158,7 \pm 15,8 / 87,3 \pm 14,6$ мм рт.ст.) в возрасте 56,6 $\pm 10,2$ лет, которым была проведена РД. Среднесуточное АД, масса левого желудочка (трансторакальная эхокардиография), высокочувствительный С-реактивный белок (вч-СРБ), интерлейкин-1ß (ИЛ-1ß), ИЛ-6, ИЛ10 и фактор некроза опухоли альфа (ФНО-а) оценивались на исходном уровне и через 2 года после РД.

Результаты. Исходная частота гипертрофии левого желудочка (ГЛЖ) составляла 90,2\%. Через два года после РД, МЛЖ и межжелудочковой перегородки (МЖП) значительно снизились ( $<<0,05$ для обоих показателей). Уменьшение массы миокарда ( $\Delta$ Млж>0 г) было зарегистрировано у 24 пациентов. Уменьшение МЛЖ сопровождалось статистически значимым снижением уровней воспалительных маркеров - вч-СРБ на 38,3\% (p=0,031), ФНО-а на 60,7\% ( $p=0,009)$, ИЛ-1В на 71,1\% ( $p=0,001)$, ИЛ-10 на 58,2\% ( $p=0,001)$. У пациентов, у которых не наблюдалось снижение МЛЖ, только ФНО-а значительно снизился $(-68,8 \%, p=0,001)$. Корреляции между изменениями МЛЖ и воспалительными маркерами через 24 месяца после РД выявлено не было.
Заключение. РД у пациентов с резистентной АГ может оказывать долгосрочное кардиопротекторное влияние в виде снижения МЛЖ, что частично может быть связано с уменьшением выраженности системного или миокардиального воспаления.

Ключевые слова: резистентная артериальная гипертензия, кардиопротективный эффект, гипертрофия левого желудочка, ренальная денервация, воспаление.

Отношения и деятельность: нет.

ID исследования: NCT 02667912.

Поступила 31/08-2020

Рецензия получена 11/12-2020

Принята к публикации 22/01-2021

Для цитирования: Ситкова Е. С., Мордовин В.Ф., Пекарский С. Е., Рипп Т. М., Рябова Т.Р., Фальковская А. Ю., Личикаки В.А., Зюбанова И. В., Баев А. Е., Гусакова А. М. Положительные эффекты ренальной денервации на маркеры воспаления и массу левого желудочка. Результаты 24-месячного наблюдения. Кардиоваскулярная терапия и профилактика. 2021;20(2):2678. doi:10.15829/1728-88002021-2678

AH - arterial hypertension, BP - blood pressure, DBP - diastolic blood pressure, eGFR - glomerular filtration rate (by MDRD formula), hsCRP - high sensitivity C-reactive protein, IL - interleukin, IVS - interventricular septum, LVM - left ventricle mass, LVM - left ventricular hypertrophy, RDN - renal denervation, RH - resistant hypertension, SBP - systolic blood pressure, TNF- $a$ - tumor necrosis factor alpha.

\section{Introduction}

Despite the progress in the development of antihypertensive pharmacotherapy a prevalence of uncontrolled arterial hypertension $(\mathrm{AH})$ is still very high. Major classes of antihypertensive drugs can reduce blood pressure (BP), on average, by $-9.1 /-5.5 \mathrm{~mm} \mathrm{Hg}$ when administered as monotherapy and around $-30 /$ $-15 \mathrm{~mm} \mathrm{Hg}$ when 3 drugs are used in combination [1]. It is obviously not enough for effective treatment of severe AH with BP higher than $180 \mathrm{~mm} \mathrm{Hg}$. Therefore, a significant proportion of treated hypertensives remain uncontrolled or treatment-resistant. The risk of stroke and myocardial infarction in patients with resistant hypertension ( $\mathrm{RH})$ is twice as high as in those with controlled hypertension.

According to meta-analysis of cross-sectional and longitudinal studies including 3325 patients, left ventricular hypertrophy ( $\mathrm{LVH})$ is diagnosed in 55$75 \%$ of patients with $\mathrm{RH}$ [2]. A negative effect of $\mathrm{LVH}$ on clinical course and the outcomes of myocardial infarction has been shown in a large observational study [3]. Also, LVH negatively affected the infarct size in experimental research [4]. The LVH is independent predictor of systolic dysfunction [5], sudden cardiac death and cardiovascular death. Reduction of LVH or left atrium size due to antihypertensive pharmacotherapy can have a positive effect on a risk of major cardiovascular events [6].

A role of inflammation in the development of $\mathrm{AH}$ and hypertensive organ damage has been widely discussed in recent decades. A variety of pro- inflammatory and inflammatory markers have been studied for their relationship with the progression of the disease, especially, high sensitivity C-reactive protein (hsCRP), interleukins and tumor necrosis factors.

One of the most promising therapeutic developments potentially capable to solve the problem of $\mathrm{RH}$ is catheter based renal denervation (RDN). Treatment of RH with RDN demonstrates regress of $\mathrm{LVH}$, but with low predictability, and even in the absence of BP response. Also, long-term effects of RDN on LVH are not well studied.

Aim of the study is to determine the long-term effect of RDN on left ventricular mass (LVM) and inflammatory markers in patients with resistant hypertension.

\section{Material and methods}

We performed a retrospective analysis of the data from the single center study of RDN in RH patients conducted in the Cardiology Research Institute of Tomsk National Medical Research Center.

Study inclusion criteria were: hypertensive patients of both genders, 18-80 years old, office BP $>160 / 90 \mathrm{mmHg}$ (systolic /diastolic, respectively) despite treatment with maximum tolerated doses of 3 antihypertensive drugs in, one of which was a diuretic. All patients provided written informed consent before inclusion in the study. The patients were excluded if they had secondary hypertension, 24-h mean systolic blood pressure (SBP) $<135 \mathrm{~mm} \mathrm{Hg}$, glomerular filtration rate (by MDRD formula) (eGFR) $<30 \mathrm{~mL} / \mathrm{min} /$ $\mathrm{m}^{2}$, pregnancy, extended disease of the renal arteries, severe comorbidity significantly increasing risk of the intervention. 
Table 1

Baseline patients' characteristics

\begin{tabular}{ll}
\hline & Mean \pm SD or (\%) \\
\hline Number of patients & 41 \\
\hline Age, years & $56.6 \pm 10.2$ \\
\hline Gender, males & $14(34.1 \%)$ \\
\hline Duration of the disease, years & $15.7 \pm 7.8$ \\
\hline Diabetes & $21(51.2 \%)$ \\
\hline CAD & $21(51.2 \%)$ \\
\hline 24 h SBP, $\mathrm{mmHg}$ & $158.7 \pm 15.8$ \\
\hline L4 h DBP, mmHg, $\mathrm{g}$ & $87.3 \pm 14.6$ \\
\hline Serum creatinine, $\mu$ mol/l & $262,1 \pm 72.3$ \\
\hline eGFR, ml/min/m ${ }^{2}$ & $81.6 \pm 19.2$ \\
\hline BP lowering drugs: & $77.7 \pm 17.3$ \\
\hline - Beta-blockers & $4.3 \pm 0.9$ \\
\hline - ACE-inhibitor & $33(80.5 \%)$ \\
\hline - Calcium channel blockers & $22(53.7 \%)$ \\
\hline - Diuretic & $32(78.0 \%)$ \\
\hline - Antagonist of aldosterone & $41(100 \%)$ \\
\hline - Angiotensin receptor blockers & $15(36.6 \%)$ \\
\hline - Alpha-adrenoblockers & $15(36.6 \%)$ \\
\hline - Centrally acting & $1(2.4 \%)$ \\
\hline
\end{tabular}

Note: CAD - coronary artery disease, ACE-inhibitor - angiotensin converting enzyme inhibitor.

The patients meeting eligibility criteria underwent RDN procedure and were followed up for a period up to 3 years. Patients were instructed to maintain concomitant drug therapy as stable as possible during the follow-up.

There were 6-, 12-, 24- and 36-months follow-up examination to assess the effectiveness and safety of renal denervation. The results of the annual observation were presented earlier. This study presents research data from $41 \mathrm{RH}$ patients completed 2 year follow up. Baseline characteristics of the patients and structure of antihypertensive pharmacotherapy are summarized in the table 1 . There were no deviation from the schedule of taking the drugs. Control was carried out by interviewing patients.

The following parameters were analyzed at baseline and 24 months after treatment:

1. 24-h mean SBP and DBP obtained from ambulatory BP monitoring. Only data with more than $80 \%$ of successful measurements were accepted for the analysis.

2. The thickness of interventricular septum (IVS) and posterior wall of left ventricle, LVM and indexed LVM assessed by transthoracic echocardiography. LVH was diagnosed if indexed LVM was more than $95 \mathrm{~g} / \mathrm{m}^{2}$ and $115 \mathrm{~g} / \mathrm{m}^{2}$ for women and men respectively.

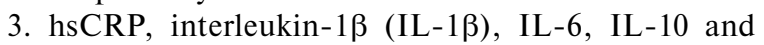
tumor necrosis factor alpha (TNF- $\alpha$ ) measured in a blood serum by enzyme-linked immunosorbent assay (ELISA) in the absence of acute inflammation or exacerbation of chronic pathology.

4. Serum creatinine, eGFR (MDRD).

Statistical analysis: Measurement data that followed a normal distribution were expressed as mean $\pm \mathrm{SD}$. Betweengroup differences in continuous (interval) variables were
Table 2

Structure of antihypertensive therapy at baseline and 24 months after RDN

\begin{tabular}{lll}
\hline Parameters & $\begin{array}{l}\text { Baseline } \\
\text { (\% of patients) }\end{array}$ & $\begin{array}{l}\text { 24 months } \\
\text { (\% of patients), }\end{array}$ \\
\hline Beta-blockers & 80.5 & $82.9, \mathrm{p}=0,78$ \\
\hline Diuretic & 100 & 100 \\
\hline ACE-inhibitor & 53.7 & $60.9, \mathrm{p}=0,50$ \\
\hline Calcium channel blockers & 78.0 & $87.8, \mathrm{p}=0,24$ \\
\hline Angiotensin receptor blockers & 36.6 & 36.6 \\
\hline Alpha-adrenoblockers & 2.4 & $0, \mathrm{p}=0,31$ \\
\hline Centrally acting & 21.9 & $24.3, \mathrm{p}=0,79$ \\
\hline Antagonist of aldosterone & 36.6 & $41.5, \mathrm{p}=0,65$ \\
\hline
\end{tabular}

Note: ACE-inhibitor - angiotensin converting enzyme inhibitor.

Table 3

Levels of inflammatory markers before and 24 months after RDN in patients without regress of LVM

\begin{tabular}{llll}
\hline & Baseline, M (SD) & $24 \mathrm{~m}, \mathrm{M}(\mathrm{SD})$ & $\mathrm{p}$ \\
\hline $\mathrm{IL}-1 \beta, \mathrm{pg} / \mathrm{ml}$ & $3.4(3.1)$ & $0.9(0.3)$ & 0.10 \\
\hline $\mathrm{IL}-6, \mathrm{pg} / \mathrm{ml}$ & $3.7(3.2)$ & $3.3(2.4)$ & 0.65 \\
\hline $\mathrm{IL}-10, \mathrm{pg} / \mathrm{ml}$ & $5.9(4.4)$ & $2.9(1.5)$ & 0.26 \\
\hline $\mathrm{hsCRP}, \mathrm{mg} / \mathrm{l}$ & $3.8(3.4)$ & $3.5(3.2)$ & 0.53 \\
\hline $\mathrm{TNF}-\alpha, \mathrm{pg} / \mathrm{ml}$ & $5.4(3.6)$ & $1.9(1.0)$ & 0.001 \\
\hline
\end{tabular}

Table 4

Levels of inflammatory markers before and 24 months after RDN in patients with regress of LVM

\begin{tabular}{llll}
\hline & Baseline, M (SD) & $24 \mathrm{~m}, \mathrm{M}(\mathrm{SD})$ & $\mathrm{p}$ \\
\hline $\mathrm{IL}-1 \beta, \mathrm{pg} / \mathrm{ml}$ & $3.0(2.7)$ & $0.7(0.3)$ & 0.001 \\
\hline $\mathrm{IL}-6, \mathrm{pg} / \mathrm{ml}$ & $3.7(2.5)$ & $4.3(3.5)$ & 0.84 \\
\hline $\mathrm{IL}-10, \mathrm{pg} / \mathrm{ml}$ & $6.0(3.3)$ & $2.5(0.5)$ & 0.001 \\
\hline $\mathrm{hsCRP}, \mathrm{mg} / \mathrm{l}$ & $4.8(3.2)$ & $2.9(2.4)$ & 0.03 \\
\hline TNF- $\alpha, \mathrm{pg} / \mathrm{ml}$ & $4.4(3.6)$ & $1.6(0.6)$ & 0.009 \\
\hline
\end{tabular}

assessed using T-test, Chi-square test was used to asses differences in categorical variables. Continuous relationships between interval variables were evaluated using Pearson correlation coefficients, $\mathrm{t}$ statistic was used to assess a significance of the relationships. A p-value $<0.05$ was considered as significant.

\section{Results}

Two years after RDN the 24-hour BP was significantly decreased compared to baseline (-13.1/-7.4 $\mathrm{mm}$ Hg SBP/DBP respectively, $\mathrm{p}<0.001$ for both). The analysis of patient-reported data on the antihypertensive drug use has shown no significant changes in concomitant drug therapy throughout the follow-up $(4.14 \pm 0.89$ vs $4.37 \pm 0.93, \mathrm{p}<0.16)$ (table 2 ).

The baseline prevalence of LVH in the study sample was $90.2 \%$. Two years after RDN LVM was decreased 
significantly from $269.9 \pm 71.7$ to $254.6 \pm 58.1 \mathrm{~g}, \mathrm{p}=0,048$ mainly due to decrease in IVS from $14.0 \pm 1.5$ to $13.5 \pm 1.5$ $\mathrm{g}, \mathrm{p}=0,015$ whereas PW thickness did not change $(12.9 \pm 1.7 \mathrm{~g}$ at baseline and $12.8 \pm 1.7 \mathrm{~g}, \mathrm{p}=0,56)$.

Decrease in myocardial mass $(\Delta \mathrm{LVM}>0 \mathrm{~g})$ was documented in 24 patients. The regression of LVM was accompanied by significant decrease of inflammatory markers: the hsCRP by $38.3 \%(\mathrm{p}=0.031), \mathrm{TNF}-\alpha$ by $60.7 \%(\mathrm{p}=0.009), \mathrm{IL}-1 \beta-$ by $71.1 \%(\mathrm{p}=0.001), \mathrm{IL}-10$ by $58.2 \%(\mathrm{p}=0.001)$ except IL-6 that did not change (table 3).

In contrast, there was no significant changes inflammatory markers level in the absence of LVM regress $(\Delta \mathrm{LVM}<0 \mathrm{~g}, \mathrm{n}=17)$. Only $\mathrm{TNF}-\alpha$ decreased significantly $(-68.8 \%, p=0.001)$ (table 4$)$. In a both cases (with and without regress of LVH) BP decreased significantly at two years after RDN 24-h (-8.5/-5.8 and $-17.3 /-8.5 \mathrm{~mm} \mathrm{Hg}$ respectively ( $<<0.01$ for both).

There was no correlation between changes of LVM and inflammatory markers at 24 months after RDN. There were no serious adverse events associated with the RDN.

\section{Discussion}

RDN as a method of endovascular treatment of $\mathrm{RH}$ demonstrates cardioprotective effects but the magnitude of the effects is highly variable. Previous studies of cardioprotective efficacy of RDN were conducted in small patient groups and had a short duration, mainly, up to one year. The regression of LVM and atrial size after RDN was confirmed in metanalysis of 12 studies with twelve months follow up including 382 patients in total [7]. There was no relationship between cardiac changes and BP reduction after RDN in these studies. Regress of LVM and reduction of the volume of subendocardial damage assessed by contrast enhanced MRI were demonstrated in $35 \mathrm{RH}$ patients over 1 year follow-up after RDN in our center [8]. Currently there are only a few publications on the longterm cardioprotective efficacy of RDN. The study in 18 patients with RH has shown a definite 24 -month cardioprotective effect of RDN: regression of LVH was

\section{Литература/References}

1. Bramlage P, Hasford J. Blood pressure reduction, persistence and costs in the evaluation of antihypertensive drug treatment a review. Cardiovasc Diabetol. 2009;27:8-18. doi:10.1186/14752840-8-18

2. Cuspidi C, Vaccarella A, Negri F, et al. Resistant hypertension and left ventricular hypertrophy: an overview. J Am Soc Hypertens. 2010;4(6):319-4. doi:10.1016/j.jash.2010.10.003.

3. Kannel WB, Sorlie P, Castelli WP, et al. Blood pressure and survival after myocardial infarction: the Framingam study. Am J Cardiol. 1980;45(2):326-30. doi:10.1016/0002-9149(80)90654-2.

4. Koyanagi S, Eastham CL, Harrison DG, et al. Increased size of myocardial infarction in dogs with chronic hypertension and left ventricular hypertrophy. Circulation Research. 1982;50(1):55-62. doi:10.1161/01.res.50.1.55 detected in $70.6 \%$ cases, the prevalence of concentric remodeling dropped by $47.1 \%$. Cardiac changes were not related to the BP lowering after RDN [9].

The relationship between inflammation and hypertension has been shown in a number of studies [10]. Levels of IL-1 $\beta$, IL-6, TNF- $\alpha$ in hypertensive patients are significantly higher compared to normotensives [11]. In particular, it has been shown that hsCRP known as a marker of vascular inflammation and remodeling is also involved in the development of $\mathrm{LVH}$ [12], has strong association with hypertension [13] and predicts cardiovascular complications in hypertensive patients.

The experimental studies demonstrated that mechanisms of the LVH regression after RDN are not limited to the decrease in sympathetic activity and blood pressure. The levels of expression of myocardial TNF, IL-6, TLR-4 may also be relevant in this regard. An experimental study of RDN performed in spontaneously hypertensive rats has shown that compared to the control Wistar Kyoto spontaneously hypertensive rats had markedly higher blood pressure, LVMI and protein expression of TLR4, NF- $x$ B, TNF- $\alpha$ and IL- 6 in the myocardium, which were significantly reduced after RDN in contrast with sham-operated animals [14].

In 2015 a group of German authors published a study that documented a significant decrease in IL-6 and CRP whereas an increase in matrix metalloproteinases (MMP-2, MMP-9) at 6 months after RDN [15].

The main finding of our study is that the IVS thickness and LVM assessed by echocardiography decreased significantly at 24 months after RDN. Thus, the RDN in RH patients may have long-term cardioprotective effect, which at least in part may be attributed to the regress in systemic or myocardial inflammatory activity. In spite of the research limitations (small sample, absence of control group) the results obtained are scientific interest and demand continuing the research.

Relationships and Activities: none.

5. Drazner MH, Rame JE, Marino EK, et al. Increased left ventricular mass is a risk factor for the development of a depressed left ventricular ejection fraction within five years: the Cardiovascular Health Study. J Am Coll Cardiol. 2004;43(12):2207-15. doi:10.1016/j.jacc.2003.11.064.

6. Gerdts E, Wachtell K, Omvik P, et al. Left atrial size and risk of major cardiovascular events during antihypertensive treatment Losartan intervention for endpoint reduction in hypertension trial. Hypertension. 2007;49(2):311-6. doi:10.1161/01. hyp.0000254322.96189.85.

7. Lu D, Wang K, Liu Q, et al. Reductions of left ventricular mass and atrial size following renal denervation: a meta-analysis. Clin Res Cardiol. 2016;105(8):648-56. doi:10.1007/s00392-0160964-2. 
8. Sitkova ES, Mordovin VF, Ripp TM, et al. Positive effects of renal denervation on left ventricular hypertrophy and subendocardial damage. "Arterial'naya Gipertenziya" ("Arterial Hypertension"). 2019;25(1):46-59. (In Russ.) Ситкова Е. С., Мордовин В. Ф., Рипп Т. М. и др. Положительное влияние ренальной денервации на гипертрофию и субэндокардиальное повреждение миокарда. Артериальная гипертензия. 2019;25(1):46-59. doi:10.18705/1607-419X-2019-25-1-46-59.

9. Tsioufis C, Papademetriou V, Dimitriadis, et al. Long-term effects of multielectrode renal denervation on cardiac adaptations in resistant hypertensive patients with left ventricular hypertrophy. J Hum Hypertens. 2016;30(11):714-9. doi:10.1038/jhh.2015.127.

10. Dinh QN, Drummond GR, Sobey CG, et al. Roles of inflammation, oxidative stress and vascular dysfunction in hypertension. Biomed Res Int. 2014;2014:406960. doi:10.1155/2014/406960.

11. Bautista LE, Vera LM, Arenas IA, et al. Independent association between inflammatory markers (C-reactive protein, interleukin-6, and TNF-alpha) and essential hypertension. J Human Hypertens. 2005;19(2):149-54. doi:10.1038/sj.jhh.1001785.

12. Mehta SK, Rame JE, Khera A, et al. Left Ventricular Hypertrophy, Subclinical Atherosclerosis, and Inflammation. Hypertens 2007:49(6):1385-91. doi:10.1161/hypertensionaha.107.087890.

13. Blake GJ, Rifai N, Buring JE, et al. Blood pressure, C-reactive protein, and risk of future cardiovascular events. Circulation. 2003;108(24):2993-9. doi:10.1161/01.cir.0000104566.10178.af.

14. Jiang W, Tan L, Guo Y, et al. Effect of renal denervation procedure on left ventricular hypertrophy of hypertensive rats and its mechanisms. Acta Cir Bras. 2012;27(11):815-20. doi:10.1590/ S0102-86502012001100012.

15. Dörr O, Liebetrau C, Möllmann H, et al. Beneficial effects of renal sympathetic denervation on cardiovascular inflammation and remodeling in essential hypertension. Clin Res Cardiol. 2015;104(2):175-84. doi:10.1007/s00392-014-0773-4. 